\title{
Augustinian Recollect Contributions to the Church History and Cultural Patrimony of Palawan
}

\author{
Ret. Prof. Emmanuel Luis A. Romanillos \\ University of the Philippines-Diliman, Quezon City, Philippines \\ elaromanillos@gmail.com
}

\begin{abstract}
Understanding our past determines actively our ability to understand the present. So how do we sift truth from belief? How do we write our own histories personally or culturally and thereby define ourselves? How do we penetrate years, centuries of historical distortion to find original truth? -Dr. Robert Langdon in Da Vinci Code
\end{abstract}

The past is a source of knowledge, and the future is a source of hope. Love of the past implies faith in the future.

-Dr. Stephen E. Ambrose (1936-2002), American historian and biographer

\section{Prologue: Not Merely natural beauty}

The international travel guide Lonely Planet published in the net its "Best in Travel" lists where Palawan landed at $9^{\text {th }}$ place in the "Best Value Travel Destinations for 2014" list. The list consists of such awesome and paradise-like choice destinations as Italy, Greece, Portugal, Nicaragua, India and Fiji, where, as the website puts it, "your wallet will smile at the memories for years to come." It counsels everyone: "When times are tight we suggest you travel more, not less - but pick carefully" and, yes, Palawan is one of such few picks. Lonely Planet's Tom Hall gives us a great review of this Natureblest destination on 28 October 2013:

Jungle rivers, limestone cliffs and awesome beaches - Palawan's no secret, but it certainly rewards those who visit. This mix, combined with stand-out attractions such as Puerto Princesa Subterranean River National Park and the Bacuit Archipelago (all available at a competitive price), makes it a greatvalue pick for old Asia hands and novices alike. A journey on from Palawan leads to the Calamian Islands where apparently Alex Garland saw the strip of sand that inspired The Beach. Watch out for the May to October monsoon: it brings heavy rain, usually in the afternoon. ${ }^{1}$

\section{Palawan in the Eyes of the Augustinian Recollects}

Over three decades ago I wrote an article as mandated by former Cuyo missionary and then vicar provincial Father Jesús Sobejano. The paper was to be read at a post-prandium celebration of Palawan Bishop Gregorio Espiga's silver jubilee at San Sebastian College in September 1980. This former mission territory of the Augustinian Recollect Order has brought about a famous apothegm: De Palawan al Cielo, From

\footnotetext{
1 "Lonely Planet's best value travel destinations for 2014," in http://www.lonelyplanet.com /travel-tips-and-articles/lonely-planets-best-value-travel-destinations-for-2014. Retrieved 2 November 2013.
} 
Palawan to Heaven. That was the title of my talk understandably aborted because the ruckus and din caused the clash of hundreds of plates, spoons and forks as well as the celebratory conversations and jubilant laughter.

Palawan was truly many things to many Augustinian Recollect priests and brothers. Indeed, one of the favorite ones was to affirm that Palawan was a stepping to heaven. There I wrote with some recent now:

The annals of the evangelization of Palawan are etched in blood and sweat, in tears and fears. An archipelago in itself with 1,769 islands with a total land area of 14,745 sq. kms., Palawan truly posed a great challenge to some 200 Augustinian Recollect missionaries who labored for 365 years in its frontier mission stations from 1622 to 1987. [We have to add the return of the Filipino Recollects in 2005 to Inagawan of the Apostolic Vicariate of Puerto Princesa and their assignment in 2008 in Casian Island of the Apostolic Vicariate of Taytay.] The barely accessible towns-stemming from lack of road infrastructures-and island towns together with untold hazards of hopping from island to island through shark-infested waters were familiar to both missionaries and inhabitants whether these be Cuyunin, Agutaynon, Tagbanua, llocano, Visayan, or Tagalog.

The great havoc of malarial Anopheles was since time immemorial a singular cause of distress and dread for both dwellers and missionaries of yore of these western Philippine frontier lands. Only a handful of Recollect priests were spared from the dreaded tropical malady. Even the founding missionary of Puerto Princesa City, first penal colony chaplain, first military chaplain in Palawan-Saint Ezekiel Moreno de la Virgen del Rosario (1848-1906) - had a critical bout with malaria that almost cost him his dear life. He was constrained to leave the new colony for Manila, thus ending his ten-month sojourn in Inagawan, Aborlan and Puerto Princesa.

The biggest thorn and constant source of alarm for both missionary and native in Agutaya, Cuyo, Linapacan, Dumaran, Taytay, Busuanga, Culion and other Calamianes islands and islets, was the seemingly endless series of ruthless Moro slave-trading and raiding expeditions against coastal towns and settlements from the $17^{\text {th }}$ till mid- $19^{\text {th }}$ century.

For some Recollects, Calamianes is synonymous - aside from rhyming perfectlywith the Castilian term calamidades [calamities, disasters] that included strong typhoons, monsoon rains, Moro assaults, treacherous gigantic waves. According to Father Federico de la Rosa OAR, secretary of Bishop Gregorio I. Espiga, the myriad trials, fatigues, martyrdoms and deaths concomitant to their evangelization tasks have given rise to a familiar Recollect phrase: De Palawan al Cielo, from Palawan to Heaven. ${ }^{2}$

In the past, Palawan with its far-flung parishes and secluded missions was likewise deemed as a fitting place of exile, a lonely nook in abject isolation and silence, for those who had committed violations of the monastic vows. It was an appropriate

\footnotetext{
2 Emmanuel Luis A. Romanillos. From Palawan to Heaven. $375^{\text {th }}$ Anniversary of the Evangelization of Palawan, Cuyo and Calamianes, in The Augustinian Recollects in the Philippines. Hagiography and History (Quezon City 2001) 125-134.
} 
place to perpetually meditate on the Four Last Things, an extended hermitage of a never-ending spiritual retreat, far from the madding crowd, sadly bereft of community life with confreres in religion.

Now everything has changed. Now Palawan is a major training ground of youthful newly-ordained Augustinian Recollect priests under the wise guidance of mature confreres. These senior Recollect confreres might have had their rigorous missionary experiences and training in Zambales and in Sierra Leone in West Africa.

\section{Recollect Evangelization Work in Cuyo and the Calamianes}

On 27 August 1622, Bishop Pedro de Arce (†1645) of the Diocese of the Most Holy Name of Jesus handed the spiritual administration of Cuyo and the Calamianes Islands, which belonged to his vast jurisdiction, over to Father Andrés del Espíritu Santo, vicar provincial of the Augustinian Recollects in the Philippines. The mission station had been vacated by its parish priest, Father Juan de Santa Cruz of the diocesan clergy. We do not know the length of stay of the last secular priest. The Recollect vicar provincial was to send "the competent and necessary ministers [...] to whom commission and jurisdiction have been given in order to administer the holy sacraments of the Church by teaching them all and preaching to them the holy Gospel."3

In behalf of the Spanish monarch and by virtue of the Royal Patronage, Don Alonso Fajardo de Entenza, governor general in 1618-1624, confirmed on 23 February 1623 the decree of Cebu Bishop Pedro de Arce that granted the spiritual administration of Cuyo and the Calamianes Islands to the Congregation of the Augustinian Recollects. ${ }^{4}$ Salaries and stipends for the Augustinian Recollect missionaries who were mandated to teach the natives Christian doctrine, preach to them the Gospel of Christ, and administer the sacraments of the Holy Mother Church were to be shouldered by the colonial coffers. The colonial government of Manila was mandated as well to fully support the material necessities for divine worship.

The pioneering four Recollect missionaries were the superior Father Juan de Santo Tomás (†1631), Father Francisco de San Nicolás (1590-1652), Father Diego de Santa Ana (1599-1652) and Brother Francisco de la Madre de Dios (†1638). ${ }^{5}$ In early $1623,{ }^{6}$ they landed at Cuyo which was described as "a very fertile land, suited for all kinds of crops, with an abundance of animals and edibles, endowed with a wonderful temperature, with lovely and calm skies."

The inhabitants of Cuyo showed a favorable disposition towards the Recollect missionaries and very soon accepted the Christian religion without much difficulty. Two

\footnotetext{
${ }^{3}$ Licinio RuIz, Sinopsis histórica de la Provincia de San Nicolás de Tolentino de las Islas Filipinas (Manila 1925) vol. 1, 352-353; Patricio MARCELLÁN, La Provincia de San Nicolás de Tolentino de las Islas Filipinas (Manila 1879) 171.

${ }^{4}$ Sinopsis histórica, 354.

${ }^{5}$ As regards the number of the first Recollects, we follow Angel Martínez Cuesta's Historia de los Agustinos Recoletos (Madrid 1995) (vol. 1, p. 379) and Licinio Ruiz's Sinopsis histórica whose frequently cited source could be José de la Concepción's Reseña histórica (1750); cf. p. 354 . Marcellán erroneously claimed there were five Recollect pioneers - all unnamed except for the prior Father Juan de Santo Tomás-in his 1879 book, cf. 173.

${ }^{6}$ Angel Martínez CUESTA, Historia I, 379.

7 MARCELLÁN, 173.
} 
thousand inhabitants were shortly after converted to Christianity in Cuyo. Their natural docility, inherent religiosity, stimulated further by the zeal of Spanish ministers of the Gospel of Christ, prepared the natives for the Catholic teachings.

In a span of a few months, the Augustinian Recollect missionaries had travelled to the main islands of the Calamianes and preached the Word of God in those farflung areas. The settlements and much later towns with their churches and convents subsequently created by the pioneering ministers of Jesus Christ were Barbacán, Dumarán, Linapacan and Busuanga. They had much earlier established the towns of Agutaya and Taytay, which later on served as the base for missionary trips to Taytay and Paragua in the mainland. ${ }^{8}$

\section{Cuyo, cradle of Christianity}

The first Recollects observed that the early inhabitants of Cuyo and the Calamianes offered sacrifices to the moon through shamans called mangalog in order to obtain healing of ill relatives and assistance at the time of death. They also sought the services of priestesses called babaylanas who rendered worship to various deities and spirits. The natives did not have any social or political life at all. They lived in complete freedom, scattered in various areas, or in the mountain fastness and forests without forming a single community.

It was further observed that the Cuyonins regularly waged war against one another but, on the whole, they were especially scared of the ruthless Moro slavetraders and foreign enemy whom they dared not engage in warfare. ${ }^{9}$ At the unexpected arrival of foreign or Moro invading forces which composed of several caracoas and hundreds of warriors, the inhabitants of Cuyo merely rushed to the safety of the mountains. Those left behind in the scattered settlements had to fend for themselves, or they were hauled off as slaves to Mindanao and Sulu or they turned into victims of kidnap for future ransom.

The island of Cuyo had a regular missionary even when the colonial government in Manila ordered the pull-out of the garrison and European soldiers from the Calamianes towns and forts for fear of a massive invasion by the Moros. When the settlements were created into towns or parishes, a Recollect parish priest had already fixed his residence always in Cuyo. ${ }^{10}$ They had eventually formed Christian community, attentively learned the basic Christian prayers, eagerly observed Catholic rites, and gradually did away with their indigenous animistic customs. A Recollect writer poses this question:

Which came first the fort or the church of Cuyo? What attracts the tourists these days is the fort, an impressive opus of engineering and witness of an eventful history that can tickle the visitor's imagination. But the fort would not have been set up if not for religious reasons, and in the final analysis, in the service of the church. And at present, it is but a [seeming worthless] relic of the past, while the church continues to be seat of the parish of Saint Augustine, now belonging

\footnotetext{
${ }^{8}$ Sinopsis histórica, 356.

9 MARCELLÁN, 172.

10 MARCELLÁN, 173.
} 
to the Apostolic Vicariate of Taytay, created in 2002. How true does it is in our opinion what Father Jarauta said in 1931:

The church is old, quite well-preserved, and it's surrounded by a bulwark or wall of cut stones, constructed by our missionaries for the defense against the attacks carried out by the Moros. ${ }^{11}$

In his 2008 article, the Recollect author Father Pablo Panedas observes that there is a small lateral door that leads to what is called casamata in the front rampart and towards the interior of the fort. That existent door is crowned with an arch connecting directly to the church from where one goes to the kuta through another wide door. In not so distant past, the missionaries who served Cuyo and the Calamianes Islands had come with such amusing comments considering the church is the only one in the world which one could enter ordinarily with a car. The stone fort is well-preserved simply because the clergy and parishioners still use the church edifice inside the ramparts and the convent as well until recently.

It is public knowledge that uninhabited structures like the Recollect stone forts, ruined churches, cemeteries and belfries have always been invaded by thickets and unstoppable vegetation. The growing forest usually enveloped the structures in no time. Hence the apostolic prefect of Palawan in 1904-1936 Msgr. Victoriano Román used to shell out the yearly of US $\$ 10.00$ to pay for the maintenance of the Fort of Taytay. The missionaries did the same in Cuyo. It is no wonder that the abandoned colonial edifices can be viewed presently in their ancient grandeur and majesty only in ecclesiastical archives. ${ }^{12}$

\section{Saint Augustine Parish Church of Cuyo}

The parochial church of Cuyo is as old as the fort, having been constructed by Father Juan de San Severo during his sojourn of nine years in the island (1686-1695). The distant belfry can be mistaken for a control tower of an airport. It was constructed on one of the ramparts during the reconstruction carried out in 1827. Observers affirm that interior of the church is rough albeit impressive. It is not simply due to the walls which are more than a meter thick. Every visitor is impressed by the simplicity and bareness of the church interior. It is bereft of lateral chapels, retables or any other decor. There are a few holy icons. In the 1990s one could view the original tiles of the floor. The altar is on its highly attractive silvery splendor, a donation of the Ponce de León family. Such an impression all the more highlights the disproportionate height, needed in order to allow fenestration, and the absence of a ceiling providing us with an open view of the roof.

The commemorative marker in the facade informs the visitor that the fort of Cuyo was-deservedly-declared in 1939 as a National Historical Landmark.

\section{Moro Raids against Christian Calamianes missions}

It was the unhappy lot of the Augustinian Recollects who arrived in Manila

\footnotetext{
11 Pablo PANEDAS, Las Iglesias recoletas hoy en Filipinas, in Recollectio 31-32 (2008-2009) 340; Jarauta, 74.

12 Ibid., 341.
} 
in May 1606 to be assigned to far-flung, isolated and the most difficult areas of evangelization, "exposed to the raid and plunder by their neighbors, the Moros.

Still and all, they earned the acclaim from the archbishop of Manila who wrote the Spanish monarch in 1751: "even though they were the last workers in the tasks [...] they merited the daily wage as the first workers compensating their lateness though not of their doing with the unceasing zeal in their efforts for the increase of Christian communities, without sparing any peril at sea and the great persecution of the adjoining Moros."13 A little over a decade after their arrival in Cuyo and the Calamianes as well as in Mindanao, the Moro pillage of Christian missions under the Recollects began. With respect to the destruction, pillage, captivity and mayhem, the Recollect contemporary chronicler Father José de la Concepción remarked: "In a brief period of time, the [Moros] left the Province [referring to Calamianes and Paragua] without churches, with population centers, with icons, with sacred vessels and without ministers." ${ }^{14}$ Saint Nicholas Province could bear any more tragic events and its terrible consequences.

In 1659, they returned their missions to the bishop of Cebu. But in 1676, Calamianes was entrusted to them once more after being promised with forts, arms and ammunitions. A fort was constructed in 1719 in Taytay which was to defend a land area of more than 440 kilometers. The Moro havoc continued unabated in Palawan, Cuyo and Calamianes, in 1730 thereafter, reaching as far as Romblon, Tablas and Mindoro. The prior provincial reported that Saint Nicholas Province lost "more than 10,000 souls - dead and captive-in the duration of the Moro raids.

In 1752, the Moro hostilities spread to Caraga, Tandag, Siargao, Butuan even to the Jesuit-controlled island of Leyte. They sacked the Recollect missions of Mindoro, Burias, Ticao, Masbate, Romblon, Banton, Tablas, Sibuyan and Simara. ${ }^{15}$ They even reached Luzon from Mariveles and Zambales to Sual in Pangasinan. For lack of any mountain refuge, a considerable number of Christian believers in the small islands fled to the safety of Luzon, Panay and Leyte. Despite their protracted siege, the raiders failed to capture the capital of Romblon where priests and parishioners were armed to the teeth, equipped with ammunitions and food provisions and defended by cannons, forts and ramparts. ${ }^{16}$

By 1753, the Christian communities in the Calamianes were defended by forts and bulwarks. In Cuyo, Agutaya and Culion, the parishioners and their ministers had to stay within the safety of their forts, but "the fields, fruit trees and livestock" were left for the Moros to grab everything to their hearts' content. In 1754, Taytay was raided and over a hundred were taken captive. Next stop was Calatan, an old parish near Culion, which was razed to the ground.

\footnotetext{
${ }^{13}$ José Luis SÁENZ, Invasiones de los moros filipinos en los ministerios agustinos recoletos a mediados del siglo xviii: sus repercusiones en la vida social y religiosa de las misiones, in BPSN 74 (1985) 10.

14 Ibid., 11.

15 Ibid., 15-17.

16 Ibid., 17.
} 
In eastern Mindanao, in a 1755 report to the Recollect vicar general, the provincial declared that over five thousand Christians were either killed or captured. This figure did not include the great number of non-Christian casualties in the mountain regions of Caraga. In the 1623-1641 period, six Recollects were slain; one religious was chopped to pieces. In the 1652-1776, thirteen religious were seized: five were murdered, two perished in captivity, five were ransomed, and one was declared missing, but presumed dead. ${ }^{17}$ The long siege brought about tensions, hunger and fear. Houses and harvests set afire. Fruit trees cut down. The captives turned to slaves and in the Celebes were sold to the Dutch. Maidens and married women were forced to become concubines of the Moros in Mindanao and Sulu. Some inhabitants of Calamianes and those towns near Taytay forged a pact with the Moros and became their vassals and committed themselves to pay the corresponding tribute. ${ }^{18}$

Since time immemorial, the Recollect response to the Moro raids was to construct forts, bulwarks, watchtowers and other defenses in their spiritual jurisdiction, with the willing assistance by their parishioners. Thus, fortifications were erected in Siargao, Caraga, Surigao, Catarman in Camiguin, San Jacinto, Romblon, Cuyo, Taytay, Agutaya and Culion. Such gigantic effort produced palpable results: the raids gradually lessened. Vigilance was always the order of the day. The people increasingly stood their ground and defended themselves courageously.

The religious minister had also to teach his people how to handle arms, like cannons and arquebuses. He had to devote his precious time to constructing fortifications, providing cannons, guns and gunpowder and assign sentinels day and night. Most of all, he had to preach the Word of God, to administer the sacraments of the Church, to be a witness of the salvific mission of Christ which after all constituted the primary duties of priesthood and religious vocation. After the pillage, the minister had to rebuild the temple of God, convent and other public edifices. He had to console the grieving families. Thus, here we find the missionary zeal at its best. In 1760 , the prior provincial Juan de la Concepción once wrote the monarch in Spain about the spiritual conquest of Paragua [Palawan] with its "numerous multitude of over 40,000 souls, with a beautiful readiness to receive baptism" but the Recollect prelate added that it was necessary to free them first from the scourge of the Moros from Jolo. ${ }^{19}$

Two hundred years after, in 1872, Saint Ezekiel Moreno witnessed for himself the Palaweños' inherent "dread for Joloans," even as he forewarned future Recollect workers in the Lord's vineyard about the harsh conditions in Palawan. In his letter to the prior provincial in Manila on 12 September 1872, the Recollect missionary wrote about this traditional fear:

I believe I have explained to your reverence about the conditions where one shall find himself or the missionaries who may go there shall find themselves. They have to suffer consequent deprivations from living among non-believers and the great labors of catechizing. In the formation of towns, it behooves to suffer all these, as it well-known. Likewise the greatest inconvenience are the

\footnotetext{
17 Ibid., 19.See footnote 47.

${ }^{18}$ Ibid., 31.

19 Ibid., 32.
} 
caracoas from Jolo, although there have not been too many [Joloans], for whom the natives have a great dread. ${ }^{20}$

The most beautiful pages of the mission history of the Augustinian in the Philippines were written at that time when pastor and parishioner forged their spiritual ties through those shockingly difficult periods of history they underwent together, confronting the common archenemy of Christian beliefs and morals, of their social and spiritual lives, and coming out strong and steadfast in their faith in Christ and in His Church even to these days.

\section{Recollect Martyrs of the Calamianes}

Since the early age of Christian persecution in the Roman Empire, it has been a traditional teaching that the blood of martyrs is the seed of new Christians. ${ }^{21}$ The Apostles suffered martyrdom in their zeal to spread the Word of Christ. There was even a time in the ancient period of Church History when Christians eagerly and fearlessly sought the palm of martyrdom. The shedding of the martyr's blood was also a reality in the conversion of the New World. This was true as well in the Calamianes at the hands of Moro raiding forces. The Augustinian Recollects of yore had their fair share of sacrifice and martyrdom in their task of evangelization in those Christian communities widely scattered in remote islands.

So that the memory of their sacrifices shall be not erased from the memory of present-day Christians, we now recall their names and circumstances of their deaths. There was a crystal-clear evidence of hatred of the Christian faith on the part of those executioners who made fun of the ministers of Christ and desecrated and set their churches and convents afire and carted off with the sacred vessels and icons of the Catholic religion.

Father Francisco de Jesús María, OAR. The Recollect prior of Cuyo was captured in 1637 by Tagal, Sultan Kudarat's brother. Father Francisco de Jesús María was killed during the skirmish between at sea between Spanish troops and Tagal's Moro forces. ${ }^{22}$ Sultan Kudarat had led an armada of caracoas across the Calamianes, seizing the inhabitants, burning towns and robbing what they could. In Cuyo, the Moro salvetraders plundered the town, raided the convent, desecrated the chalices for the Mass and other sacred vessels and candleholders, committed all kinds of sacrilege against the revered Christian icons and paintings, by flaunting proudly their disdainful acts and chopping off the hands and feet of the Crucified Christ. The Cuyonons fled to the safety of the mountains leaving the Recollect parish priest alone. The missionary was seized immediately and taken captive by the Moros. The Moro caracoas encountered

\footnotetext{
${ }^{20}$ Ángel MARtínez CUesta [editor]. San Ezequiel Moreno. Obras completas, vol. 1 (Madrid 2005) 132. Emmanuel Luis A. Romanillos, Bishop Ezekiel Moreno, An Augustinian Recollect Saint Among Filipinos (Quezon City) 61.

${ }^{21}$ MARCELLÁN, 184-185.

${ }^{22}$ Francisco SÁDABA, Catálogo de los religiosos agustinos recoletos de la Provincia de San Nicolás de Tolentino de Filipinas desde el año 1606, en que llegó la primera misión a Manila, hasta nuestros días (Madrid 1906) 67.
} 
the Spanish boats in the Calamianes. In the ensuing sea battle, the Recollect was cut down by friendly fire. Father Francisco de Jesús María agonizingly perished from his serious wounds, but not without the prior conversion of Tagal and four Moro fighters to Christianity. ${ }^{23}$

Father Juan de San Nicolás, OAR. Two Recollect missionaries in the brave defense of their flock in Calamianes were martyred in the same year 1637. In 1636, both were missionaries of Linapacan where they were seized by Sultan Kudarat and his Moro raiders and later taken as captives to Basilan. When the Spanish punitive expeditionary troops started landing at Lamitan to recapture the two Augustinian Recollect priests in 1637, the furious sultan at once ordered Father Juan de San Nicolás beheaded and Father Alonso de San Agustín stabbed to death. ${ }^{24}$ Father Juan de San Nicolás was born in Madrid in whose Recollect convent he professed the three evangelical counsels in 1613. He volunteered for the Philippine missions. After his assignment as prior of Bolinao in what is now Western Pangasinan, he was named prior of Linapacan in 1635. The following year Sultan Kudarat captured him and took him to his sultanate where the captive missionary was subjected to merciless insults, blows and torture and finally received the crown of martyrdom in 1637.

Father Alonso de San Agustín, OAR. Father Alonso de San Agustín was from Cádiz, Spain. He entered the Recollect convent in Madrid where he professed the three evangelical counsels in 1613. He volunteered for the Philippine missions in 1622 . He was sent to the Calamianes as companion of Father Juan de San Nicolás and worked for the conversion of the residents for almost a year. He had just put on the Mass vestments when the Moros seized him. The invaders forthwith stripped him naked and subjected him to taunts, insults and bodily torments and then took him to Mindanao as captive for nine months. He was so emaciated and so ill that when the Spanish rescuing forces set him free him Father Alonso de San Agustín did not survive long after receiving the last sacraments. ${ }^{25}$ In 1637, the process to declare the martyrdom of the three Recollect Fathers Francisco, Juan and Alonso was opened in Manila. Archbishop Fernando Guerrero initiated the documentation process for their possible beatification as martyrs of the faith. The witnesses declared they were all martyred in odium fidei, in hatred of the Faith. All those who perished in odium fidei were deemed "Venerable" in the Father Francisco Sádaba's catalogue of Augustinian Recollects which saw print in 1906.

Brother Francisco de la Madre de Dios, OAR. Another native of Cádiz, Spain, Francisco de Guzmán entered the convent in Mexico as a young man and donned the Recollect habit. He chose his religious appellation-Francisco de la Madre de Dioswhen he professed the monastic vows as a religious brother in San Nicolás Covent in Intramuros, Manila, in October 1622. By example and exhortations, he performed various evangelization tasks of the first missionaries in Cuyo and staunchly defended

\footnotetext{
${ }^{23}$ MARCELLÁN 186-187.

${ }^{24}$ SÁDABA, 62.

${ }^{25}$ MARCELLÁN, 190
} 
the Christian faith and morals. "The zeal for the honor and glory of God," writes the biographer Francisco Sádaba, "moved [Brother Francisco] to reproach with great vehemence the aniterías or superstitions he had observed among the inhabitants; and this occasioned his death." 26 One resident remained obstinate in his errors, vices and superstitious practices and wanted to free himself from the Recollect brother's strong rebuke. He was a sangley, Chinese merchant. One day in 1638 the sangley took a pickaxe used for breaking rocks, approached the defenseless friar and struck him in the head, splitting his head into two and scattering the brains on the ground. The religious Brother Francisco de la Madre de Dios went down in history as the proto-martyr of Cuyo.

Father Francisco de Santa Mónica, OAR. A native of the Spanish city of Ciudad Rodrigo, Francisco Enríquez travelled to Manila as a layman. He asked for the religious habit from the first Recollect batch missionaries and professed the evangelical counsels in 1607 in San Nicolás convent in Intramuros. After his various assignments in Luzon, in 1629 he was dispatched to Cuyo as prior and worked zealously for the salvation of souls there. He was appointed prior in their mission at Diuail in Busuanga Island where he met his martyrdom at the hands of the Moro invading warriors. In 1638, he was deeply engrossed in mental prayer at the choir loft of the divine temple of Diuail when he was surrounded all of a sudden by Moros who mercilessly pierced him with spear thrusts. Father Francisco de Santa Mónica died very soon after "giving thanks to God for having granting the joy of dying while preaching His holy religion." ${ }^{27}$ The Recollect chronicler reported that the Moro slave-traders went on to ransack and desecrate the church, took off with its sacred vessels and burned the friar missionary's body.

Father Juan de San Antonio, OAR. A native of Mexico City, he joined the Recollect Congregation in San Nicolás convent in the Walled City of Manila in July 1639. ${ }^{28} \mathrm{He}$ was still a young religious when he was sent to Cuyo and showed his zeal in preaching for the conversion of non-believers. He was on the way to Romblon when the Moro Datu Achen captured the boat and all its passengers including the Mexican missionary. A chronicler declared that Father Juan was held captive and subjected to cruel deprivations in prison. During his captivity, beautiful women were presented to him for marriage; properties and lands were likewise offered for him to live in comfort. Instead, the missionary rebuked the Moros for such wicked intentions and taught the pirates to obey God's commandments. The Moros were burning with rage as they heard his preaching on Christian salvation to him. They then shackled him and subjected him to merciless blows. In the end, they forced the Recollect missionary to row the Moro boats, feeding him with scanty rice. He was further subjected to humiliations, nakedness, hunger and all kinds of torture until he passed away after four years of ruthless captivity, receiving his immortal crown of glory. ${ }^{29}$

\footnotetext{
${ }^{26}$ SÁDABA, 77-78.

27 Ibid., 736-737.

28 SÁDABA, 553.

${ }^{29}$ MARCELLÁN 191-192.
} 
Father Antonio de San Agustín, OAR. Born of Spanish parents in Manila, Antonio de las Misas professed in their Intramuros convent in 1612 and took the religious appellation Antonio de San Agustín. He was an exemplary religious known for remarkable traits of a great leader. He was commissioned by Governor General Hurtado de Corcuera as missionary and captain of four hundred Zambal archers during the Sangley Revolt in 1639-1640. The Spanish military officers praised the leadership and valor of the Filipino friar who was the only one obeyed by the Zambal warriors. Father Antonio was appointed to many high positions in Saint Nicholas province including his last assignment as canonical visitor of the missions of the Calamianes. He was approaching Lubang Island, north of Mindoro, when the Moros caught him and, as declared by the Jesuit historian Francisco Combés, Father Antonio was later slain by spear thrusts in odium fidei. The Moros treated the 66-year-old Filipino missionary brutally and mocked at the Virgen del Populo icon found in his possession. The Moro pirates set the Recollect missionary's native companions free. The Filipino friar's martyrdom took place in $1658 .^{30}$

More Spanish Recollect missionaries in Linapacan, Taytay and the Calamian Sea were seized in the seventeenth century and later slain by the Moros and earned the title of Venerable. Three missionaries deemed martyrs by Recollect tradition are Father Martín de la Ascención from Vera de Plasencia, Father Antonio de Santa Ana and Father Manuel de Jesus y María from Alcarria. According to witnesses, the hands of Father Manuel de Jesús y María were cut off and his breviary was placed on them to the Moros' "great jeering, mockery and contempt." ${ }^{11}$

\section{Iconic Recollects' contributions to culture and heritage in Palawan}

Father Juan de San Severo. This religious from Barcelona joined the tenth missionary expedition of the Augustinian Recollects from Spain by way of Mexico and arrived in the Philippines in August $1663 .{ }^{32}$ He was put in charge of the ministries as prior of Bislig in 1668, Romblon in 1669, vice prior of Cagayan de Misamis in 1671, provincial secretary in 1672, prior of Tandag in Surigao in 1674, prior of Siargao in 1677, vice prior of Tandag in 1674, vice prior of Bislig in 1680, vice prior of Taytay 1683, vice prior of Cuyo in 1686, and reelected in 1689, vicar provincial of Calamianes in the same year, provincial visitor of Taytay and Tancon in 1691, vice prior of Cuyo in 1692, vice prior of Taytay and vocal prior of Mariveles in 1695. Once again in 1694, he was named Provincial visitor of Calamianes, Mangarin and Calavite.

The Fort of Cuyo whose construction expenses were shouldered by the Recollect Congregation was constructed under the direction of Father San Severo. The church and convent form part of the façade of the fort. The remaining sides form the four bulwarks of the fort. They constitute a perfect square that could accommodate all the inhabitants of the town. The repeated invasions of the Moros recommended the construction of this fort and others which produced admirable results for the defense

\footnotetext{
${ }^{30}$ Ibid. 195; SÁDABA, 739-40.

31 MARCELLÁN, 192-193; 196-197

32 SÁDADA, 109-110.
} 
of the towns in past epochs. Father San Severo passed away in 1697 according to the record of a private chapter on 29 January 1698 when a new religious was appointed to take his place in the parish administration.

Father Juan Juseu de la Virgen del Carmen. ${ }^{33}$ The Recollect priest was a native of Soria, Spain where he was born on 20 October 1819. He professed the vows on 22 October 1842. After he finished his theological studies in Manila, he was assigned to Cuyo on 28 June 1845 as companion of the parish priest. On 9 December 1847, he was appointed parish priest of Agutaya. On 10 January 1851 the superiors named him assistant priest of the parish priest of Himamaylan. In 1852 he was sent to Cagayan de Misamis where he served as parish priest for about a year. He was thereafter put in charge of the parish ministries of Isabela in Basilan (1853), Catmon in Cebu (1854) and Zamboanga (1868) where he passed away on 17 May of the same year 1868. It is put on the record that when he left the ministry in Isabela he was assigned to Negros Occidental and presented as parish priest of Sum-ag, but this was only for short period of time because in the annual report of 1854 he was already parish priest of Catmon. Father Juseu authored a Gramática Cuyona when he was parish priest of of Agutaya in 1847-1851.

Father Jerónimo de la Virgen de Montserrat. ${ }^{34}$ The Catalan religious was born in Baga of the Spanish province of Barcelona of the diocese of Solsona in 1744. He made his religious profession in the Convent of Santa Mónica in Barcelona on 16 January 1766. He arrived in Manila in July 1769. On 10 December 1770 he was assigned to Taytay where he studied and mastered the dialects of Palawan and Calamianes. According to the annual report of 1776, Father Jerónimo administered the parish of Pinagaoian in Mindanao. In his obituary, he was always assigned to Calamianes. If ever he had stayed in Mindanao, it must have been for a short time. In the intermediate chapter of 1778 , we see him in Taytay as parish priest and vicar provincial. In 1802, he was elected prior of the San Nicolás Convent of the Walled City of Manila, and in 1803 he became prior of San Sebastian Convent. After the triennium he was given the honor of ex-provincial with right to vote-proof of the merits he gained in the pastoral ministry and deep appreciation the prelates had for him. Very few have been the cases when religious of the Augustinian Recollection whose peculiar character has been humility were granted such honor. In February 1807 he was put at the helm of the convent in Manila. On 11 August of the same year 1807 he was named prior presidente de San Sebastian convent where months later he died on 5 December of the same year.

Father Jerónimo de la Virgen de Monserrat wrote the Vocabulario castellanocalamiano which was written in the Convent of Saint Monica in the town and capital of Taytay, province of Calamianes. It was published in 1895. Wenceslao Retana who wrote the foreword of the book declared that it was the first Calamian dictionary.

\footnotetext{
33 SÁDADA, 432.

${ }^{34}$ SÁDADA, 336-337.
} 
Father Pedro Gibert de Santa Eulalia (1762-1843). Father Pedro was born in 1763 in San Sadurní in Barcelona and donned the Recollect habit in $1782 .{ }^{35}$ He joined the Recollect journey to Manila and arrived there in 1786. After his studies for the priesthood and sacerdotal ordination, the superiors assigned him to the Calamianes. Cuyo was his main field of evangelization tasks. Thus, he stayed most of the time in Cuyo intermittently from 1791 to 1830 . He was parish priest of Agutaya in 1788-1799. Then he was elected vice prior and novice master in 1799, prior of San Nicolás convent in 1800, and prior provincial for two terms in 1803 and 1821. He was on a canonical visit from Taytay to Culión when the Moros attacked and kidnapped Father Gibert and his secretary Father Salvador de San Luis Gonzaga. They were taken to Dumaran where negotiations for his ransom and release took place. The huge sum of 20,000 pesos was paid. Father Gibert was a prudent, learned and dedicated to study. He mastered the Cuyuno and published many books and devotionaries in the local dialect. At age 80, Father Gibert died at San Sebastian Convent in 1843.

Father Gibert wrote the Himnos y oraciones in Cuyunon to the praise of Jesus, Mary, and Joseph and instruction for the prayer of the Holy Rosary. He gave advice for a good death and prayers for a devout reader. It was posthumously published in 1882 . Another posthumous work printed in 1887 was Doctrina cristiana o mga parangadien ng critianos ig lacted nga pagturo o casaysayan sa mga pono nga camatuodan, nga taqués maclamang yg tutumanén sa tauo, nga ma laiag pagpacon sa langit. There was another version of Mga pangadien sa mga cuyonong cristianos nga sinulat sa padre exprovincial., published in Manila in 1922. A booklet in Cuyunon with 32 pages by Father Gibert was Lacted nga tocsoan nga vcasayodan sa pagradalan sa mnga cristianos, printed in 1871.

Father Gibert left behind his thick manuscript collection called Sermones varios en dialecto cuyono. Surely, the considerate parish priest bequeathed it to the younger generation of Recollect missionaries in Cuyo Archipelago. He published his three sermons in Spanish on the Immaculate Conception (1802), Saint Andrew the Apostle (1805) and Saint Barbara in Manila (1802).

Ever an observant religious, the Recollect parish priest of Cuyo and Agutaya sent to the bishop of Cebu a long manuscript account on the superstitions of the inhabitants of the Calamianes, most specially the superstitious practices of the islanders of Cuyo. The Boletín de la Provincia de San Nicolás de Tolentino published the Father Gibert's observations in its special issue for 4th Centennial of the Christianization of the Philippines in 1965 as Supersticiones de los habitantes de Cuyo, (Superstitions of the Inhabitants of Cuyo) twenty-three pages long, a great source for Palawan folklore and anthropological studies. ${ }^{36}$

1. Lacted nga tocsoan nga casayodan sa pagaradalan sa mga cristianos. Nga guinpaimprenta sa bisara nga cuyonon, sa Illmo. ig Rmo. Sr. D. Fr. Mariano Cuartero, Obispo. Manila 1871.

2. Mga Oracion sa pagdayao cay Jesús, Maria et José. Paghalad sa Santo Rosario,

\footnotetext{
35 Sádaba, 345-347.

${ }^{36}$ Boletín de la Provincia de San Nicolás de Tolentino 55 (1965) 279-302.
} 
sanda anang mga excelencias. Pagdemdem sa mga nagaanac et beta sa pagbuñag, sa masaquiten nga intauan ig Santo Viatico. May sa mga magpacasal. Turumanen sa pagdangat isarang camatayen nga matadleng et ang iba mga sa cuyunong bisara. Manila 1909.

3. Mga parangadien nga cristianos ig lacted nga pacturo o casaisayan sa mga pono nga camatundan, nga taqués maelaman ig tutumamanen sa tauo, nga maliag magpacun sa langit. Manila. 1887.

4. Parangadien sa mga cuyonong cristianos. 3rd ed. Manila: 1922.

Eduardo Abaurrea authored the Novena sa mahimayaen nga Ama si San Agustin, patron sa dia nga banua sa quinayunong bisara which was published in Manila in 1913.

A missionary in various parishes of Palawan for many years, Father Jose Francés had prepared an Agutaynin dictionary which he started during his assignment in Agutaya. He later continued it during his sojourn at San Sebastian Convent in Manila. We have not heard about the outcome of his trailblazing work.

\section{Epilogue: The Recollects returned to Palawan in $\mathbf{2 0 0 5}$}

After a hiatus of eighteen years, the Order of Augustinian Recollects has returned to Palawan. The prior provincial of the Province of Saint Ezekiel Moreno, Father Lauro Larlar, had requested the provincial secretary Father Larry Garces to accompany the all-Filipino batch of Augustinian Recollects of Father Louie Gabinete, then fresh from his Kamabai, Sierra Leone mission years, and religious brother Fray Teodulo "Dodong" Hayahay, fresh from his religious profession of the solemn vows of poverty, chastity and obedience, the historic return to the "Philippines' last ecological frontier harboring vast tracts of tropical rainforest and a huge expanse of marine wilderness," including rare and endangered species, seemed rather uneventful.

The glorious day was the $14^{\text {th }}$ day of December in 2005. They took possession of the then chaplaincy of Our Lady of Mount Carmel at Inagawan, Puerto Princesa City. The first Recollects temporarily took up residence at the Home Economics building of the Augustinian Recollect Sisters' San Francisco Javier College in Narra. ${ }^{37}$

Father Larry Garces, then provincial secretary and ex-officio provincial archivist, chronicled that arrival at Puerto Princesa-momentous at least for the historians. He wrote for posterity that it was

partly a nostalgic retracing of the historic and eventful past of our forefathers and partly a gleeful return to the awaiting embraces of the faithful who continue to be hungering for the time and witness of the sacred ministers for the nourishment of their spiritual needs.

The first Recollects accordingly arrived through the smaller island of Cuyo even as early as 1622 [sic]. And from then on, a great tradition of Recollection ensured. Among the illustrious Recollects who came to the island of Palawan was Saint Ezekiel Moreno. They were builders and organizers of churches and cities. They were good preachers and evangelizers bringing the Good News to the farthest boundaries, and the innermost territories. We are indeed very fortunate that

\footnotetext{
37Jose Ernil ALmaYo. Keeping the Fire Ablaze. Quezon City 2009.
} 
the last Recollects of the 80's left the island and its vast agricultural and coastal territories with impressive memories of hard work, religiosity and real care and concern for the flock. But that was the past-and yes, indeed, the glorious past." ${ }^{38}$

Bishop Leopoldo Tumulak, DD, military vicar general of the Armed Forces of the Philippines, declared on 19 August 2013 at the Cathedral of the Immaculate Conception, Puerto Princesa City:

How fortunate you are, people of Palawan. You have a saint who is willing to make miracles. And you have people around you to remind you of him. They are the Augustinian Recollect Fathers, the first missionaries who came to your island. Their presence here-ten of them-in Palawan is the presence of San Ezekiel. Let us praise God for this privileged presence.

\section{BIBLIOGRAPHY}

\section{Articles}

Angel MARTínez CUeSTA. The Augustinian Recollects in the $19^{\text {th }}$ and $20^{\text {th }}$ Centuries with particular reference to the Philippines, in Bulletin of the Province of Saint Ezekiel Moreno vol. 3, no. 5 (January-June 2002) 55-62.

Emmanuel Luis A. Romanitlos. From Palawan to Heaven. 375 Anniversary of the Christianization of Cuyo and the Calamianes, in Augustinian Recollects in the Philippines. Hagiography and History (Quezon City 2001) $125-134$.

JosÉ DE LA CONCEPCIÓN. Origen, progresos y estado de la Provincia de San Nicolás de Tolentino en las Islas Filipinas y de religiosos descalzos de San Agustin, in BPSN (1915-1944). For the specific issues of BPSN, see Indices de BPSN 1909-1990, 113s.

Jose Fortunato "Larry" GARCES. Destination: Palawan, in The Recoletos Observer« vol. 6, no. 4 October-December 2005) 21-24.

Jose Luis SAEnz. Actividad pastoral, social y cultural de los agustinos recoletos en Filipinas, in Recollectio 16 (1993) 249-306.

. Invasiones de los moros filipinos en los ministerios agustinos recoletos a mediados del siglo XVIII: sus repercusiones en la vida social y religiosa de las misiones, in BPSN 75 (1985) 10-33.

Licinio RuIz. Paragua o Palawan, in Sinopsis Histórica de la Provincia de San Nicolás de Tolentino de Filipinas, vol. 1, (Manila 1925) 351-466.

LUis LLORENTE. Los agustinos recoletos y las obras materiales en Filipinas, in Misiones católicas en el Extremo Oriente, Manila 1937, 405-415.

Manuel CARCELLER. Método pastoral de los agustinos recoletos en la evangelización de Filipinas, in Confer 7 (1965) 499-519.

Martín LegarRa. Los PP. Agustinos Recoletos en la evangelización de Filipinas, in Misiones Católicas en el Extremo Oriente, Manila 1937, 101-107.

Pablo PANEDAS. Las Iglesias recoletas hoy en Filipinas, in Recollectio 31-32 (2008-2009) 267-348.

Patricio Marceltán. Provincia de Calamianes, in Provincia de San Nicolás de Tolentino de las Islas Filipinas (Manila 1879) 170-197.

Pedro Herce. The Recollects in the Philippines, in Boletín Eclesiástico de Filipinas 435 (1965) 210-253.

Rafael García. Against the Moorish Pirates and Highwaymen, in The Thomasian Memoir 1948-1949, San Carlos 1949, 49-51.

\footnotetext{
${ }^{38}$ Jose Fortunato "Larry" GARCES. Destination: Palawan, in The Recoletos Observer, vol. 6, no. 4 (October-December 2005) 21-24.
} 
Rene PaglinaWAN. The Recollects in the Philippines in the 20 ${ }^{\text {th }}$ Century, in 21-22 Recollectio (Rome 1998-1999) 115-130.

_. Recollects and Palawan, in The Recoletos Observer vol. 7, no. 3 (July-September 2006) 15-18, 31.

\section{Books}

100 Years of Puerto Princesa: 1872-1972. Special centennial Anniversary issue.

Angel Martínez CUESTA. The Augustinian Recollects: Arrival in the Philippines and Spread of Missionary Activities. Quezon City 2006.

. Documentos sobre los agustinos recoletos de Filipinas en los Archivos General de Indias e Histórico Nacional de Madrid, 1789-1898. Rome 2002.

Historia de los Agustinos Recoletos I. Madrid 1995.

. The Order of Augustinian Recollects. Its Charismatic Evolution, Manila 1994.

Benjamin Locsin LAYUg. A Tourist Guide to Notable Philippine Churches. Quezon City 2007.

Eduardo ABAURREA. Novena sa mahimayaen nga Ama si San Agustin, patron sa dia nga banua sa quinayunong bisara. Manila 1913.

Emilio P. JARUDA [editor]. Commemorative Commemorative Album of the 1988-1991 Triennium. Order of Augustinian Recollects, Vicariate of the Philippines and China. Quezon City 1991.

Fidel DE BLAS. Labor evangélica de los padres recoletos en las Islas Filipinas. Zaragoza 1910.

Francisco SÁDABA. Catálogo de los religiosos agustinos recoletos de la Provincia de San Nicolás de Tolentino de Filipinas desde el año 1606, en que llegó la primera misión a Manila, hasta nuestros días. Madrid 1906.

Jesús SobejAno [editor]. Los Agustinos Recoletos: 375 Años en las Islas Filipinas, 16061981. Manila 1982.

Jose Ernil Almayo. Keeping the Fire Ablaze. Quezon City 2009.

Lucio GutiÉRREZ. Historia de la Iglesia en Filipinas 1565-1900. Madrid 1992.

Manuel CARCELLER. Historia general de la Orden de Agustinos Recoletos XII. Madrid 1974.

. Historia general de la Orden de Agustinos Recoletos XI. Madrid 1967.

. Historia general de la Orden de Recoletos de San Agustín X. Madrid 1962.

La pastoral de los Agustinos Recoletos en la evangelización de Filipinas. Marcilla Navarra Spain 1965.

Miguel Avellaneda. Continuación del Padre Sádaba, o segunda parte del 'Catálogo de los religiosos de la Orden de Agustinos Recoletos' (1906-1936). Rome 1938.

Pablo FERnÁNDEZ. History of the Catholic Church in the Philippines 1521-1898. Manila 1979.

Pedro Corro. La Orden de Agustinos Recoletos. Compendio histórico. Monachil, Granada 1930.

Pedro GIBERT. Mga pangadien sa mga cuyonong cristianos. Manila 1922.

Rafael PALMA. Historia de Filipinas. Quezon City 1968.

Regalado Trota José. Simbahan. Church Art in Colonial Philippines. 1565-1898. Manila 1992.

Rene JAVELLANA. Fortress of Empire. Spanish Colonial Fortifications of the Philippines. 1565-1898. Makati 1997. Ricardo JARAUTA. Album de la Orden de Agustinos Recoletos. Zaragoza 1931.

Samson SILLORIQUEZ. Huella de nuestra labor apostólica en las Islas Filipinas 1606-1981, in BPSN special issue $1981,33-42$.

\section{Theses}

Renier AlviolA. The Contribution of Bishop Gregorio Espiga e Infante to the Philippine Recollect Vicariate. A Thesis presented to the Graduate School of San Sebastian College. Manila 2009.

Rene PaglinaWAN. The Creation of the Apostolic Vicariate of Palawan (1955), in Recollectio (1985) pp. 98-105. 